\title{
Focused Solution Group Counseling as a Solution to Improve Career Choice Decision-making Abilities
}

\author{
M. Fatchurahman, Muhammad Andi Setiawan", Dina Fariza Tryani Syarif, Maria Efasanty \\ Department of Guidance and Counseling, Muhammadiyah University of Palangkaraya, Indonesia
}

Received August 22, 2020; Revised October 26, 2020; Accepted November 1, 2020

\section{Cite This Paper in the following Citation Styles}

(a): [1] M. Fatchurahman, Muhammad Andi Setiawan, Dina Fariza Tryani Syarif, Maria Efasanty , "Focused Solution Group Counseling as a Solution to Improve Career Choice Decision-Making Abilities," Universal Journal of Educational Research, Vol. 8, No. 12, pp. 6635-6640, 2020. DOI: 10.13189/ujer.2020.081227.

(b): M. Fatchurahman, Muhammad Andi Setiawan, Dina Fariza Tryani Syarif, Maria Efasanty (2020). Focused Solution Group Counseling as a Solution to Improve Career Choice Decision-Making Abilities. Universal Journal of Educational Research, 8(12), 6635-6640. DOI: 10.13189/ujer.2020.081227.

Copyright $\subseteq 2020$ by authors, all rights reserved. Authors agree that this article remains permanently open access under the terms of the Creative Commons Attribution License 4.0 International License

\begin{abstract}
The purpose of this study was to decide whether the Solution Focused Brief Therapy group counseling could improve the career choice decision-making ability. This study applies a quasi-experimental approach with a population of 47 students at the Muhammadiyah 1 Palangkaraya Senior High School. The sample amounted to sixteen people takes purposefully from the results of the Likert scale of career choice with low understanding criteria in career choice and the results of the recommendations of counseling guidance teachers in schools. The research data were collected by several data collection instruments, namely scales, observations, and a checklist of students' problems. The results of the experimental group's statistical analysis showed that the significance value of the t-test value was $-1,700$, with a significance level of 0.234 . Because $T$ count $<$ T table ( $\mathrm{df}=7$ ) with an amount of $-1,300>1,894$, the null hypothesis test is accepted, and the alternative hypothesis test rejects. While in the control group, the significance of the t-test value was 0.823 , with a significance level of 0.438 . The $\mathrm{T}$ count $<\mathrm{T}$ table $(\mathrm{df}=7)$ with a value of 0.823 $<1.894$ then, the nulled hypothesis test is accepted. From the results of the two groups, there was a more significant influence on the solution-focused therapy group's counseling services than the group counseling without using techniques on students' ability to make career choice decisions.
\end{abstract}

Keywords Career Choice Decision-making Ability, Solution Focused Brief Counseling, Group Counseling

\section{Introduction}

Students at the high school level have an age range of fifteen to eighteen years. Adolescence is often prone to changes in various fields, both personal, social, learning, and career. During this period, there will be many changes concerning psychosocial relationships with parents and dreams of the future. Along with the diverse development of adolescents, adolescents are too faced with various problems. As a part of the school, students cannot avoid multiple issues such as individual problems: learning problems, self-confidence, self-esteem. Group problems: adjustment, bullying, romance [1]. Individuals as unique individuals have many differences, such as intellectual abilities, personalities, self-development, characteristics, and diverse needs, and cannot equate.

The aspiration or ability to plan a career in the future is one thing that must achieve as a form that he has reached the appropriate development for his time. Students can jump into higher education at the high school level, in line with the goals of Senior High School education, namely, to prepare students who will continue their education to a higher level, in contrast to vocational high schools, which have a skill set according to their expertise, they can directly enter the work world [2].

Students in Senior High Schools must be able to prepare everything related to their career choices later. The decision is taken by yourself with a variety of careful 
considerations to no disappointment or regret in the future. Every choice that makes it appropriately accounts for, and if a problem founds later, students expect to take attitudes and actions to solve them correctly. Students who will continue their education or go straight to work cannot just do it but go through a planning or decision-making process related to the desired career. Mistakes in making career choices will have a harmful impact in the future, so there is a need for proper treatment by carrying out a meta-analytic procedure of career choice as has been done [3]. Besides that, you can also use a test tool to find suitable career options [4].

A career is a description of a person's personality and behavior related to activities and experiences in the span of a person's work journey [5]. In making career choices, a person usually adapts to their talents and interests [6]. Career consists of a sequence of experiences or a person's life, which gives continuity and tranquillity to individual attitudes and behaviors.

Career choice decisions are planning in determining career choices. Factors that influence career decision-making are internal and external [7]. Krumboltz's career theory explains factors that influence decisions, namely intrinsic factors, environment, life experience, and personal skills [8]. When a person has decided, he is expected to commit, believes in his abilities, has the power in his field, and be mature because of his personality development.

Decision-making influences my interest [9]. Health also has a significant contribution to make in determining career choices [10]. The career journey process is a long process that a person will experience from choosing options that follow the abilities and skills he has and assessing the choices made. The next stage is to mature on the choices he has made as an inseparable part of himself.

Judging from various factors that influence people in making career decisions, people are required to make career plans as early as possible, one of which is to have all matters related to career choices, when someone with career information tends to have problems in determining future careers. Therefore, it is necessary to prepare to face these conditions, namely after the educational process following their skills and abilities.

Teenagers, as a transitional period, often experience career choice problems [11]. The majority of adolescents who are not yet aware of their career choices will join with their peers to make choices. When this condition occurs, and these adolescents do not have the ability and expertise in that field, career choice problems will arise. Often also encountered adolescents who make career choices based on their parents' preferences, and most of them tend to be silent and follow them, resulting in a lack of motivation in students.

Indecision and ignorance in making career choice decisions have an impact on less realistic career choices. This choice arises because students are not interested in their fields, compulsion. Such a career choice is because the person cannot yet be independent in strengthening his career choice. Previous studies on career options have also been carried out by [12, 13, 14, 15, 16, 17]

Based on the analysis of a checklist of problem topics in Muhammadiyah 1 Palangka Raya Senior High School, the highest proportion is future problems and dreams. The results of interviews with several students were doubtful about the majors they would like to take. Counseling is one way to solve problems, as has been done by several previous studies $[18,19]$. One alternative to improve the ability to make career decisions is to use brief counseling. This counseling brief has been in use since the 1980s [20]. Solution-Focused Brief Counseling is an approach that develops based on strengths and skills in constructing the problems it is facing [21].

The metadata results for the past five years of counseling have focused on practical solutions to career problems. Other studies also show that the Solution Focused Brief Counseling is superior to dialectical counseling [22]. Short Solution Focused Counseling is also useful for dealing with various issues related to anxiety [23]. Brief counseling sees as effective in dealing with multiple problems [24]. Solution Focused Brief Counseling is an approach that emphasizes a postmodern view [25]. Solution-focused brief counseling is most effective when both the counselor and the counselee set clear goals in the counseling process [26]. A Short Solution Focused Counseling Approach emphasizes the strengths you have to transform yourself into a more effective person [27]. This approach emphasizes solutions to help the counselee. It is not too focused on the problem because the problem must be immediate to ignore, and a solution finds following the ability and choice of the counselee's heart. Although focusing on solutions does not mean that this counseling is very short, this counseling will focus more on planning to solve students' problems and arranging students on what to do. Brief counseling is an approach that aims to deal with counselees from various backgrounds because this approach does not emphasize diagnosis. This approach focuses on the counselee's frame of reference. This approach also encourages the counselee to integrate and enhance actions that have been proven successful and in accordance with their terms of reference [28, 29].

\section{Materials and Methods}

\subsection{Research Methods}

The type of research used in this research is the quasi-experimental research design Nonequivalent Groups Designs. Quasi-experimental research design Nonequivalent Groups Designs will guide so that the study's objectives can be achieved [30]. The purpose of 
this experimental research use to find a relationship between one variable and another [31], [32]. Research variables that will seek are the Ability of Career Choice Decision Making, and Solution Focused Brief Counseling. Below is a picture of the research design used.

$$
\begin{array}{llll}
\hline \text { (experiment) } & \mathrm{O}_{1} & \rightarrow \mathrm{X} \rightarrow \mathrm{O}_{2} \\
\text { (control) } & \mathrm{O}_{1} & \rightarrow-\rightarrow \mathrm{O}_{2}
\end{array}
$$

The flow of this quasi-experimental research begins by forming two groups, namely the control group and the experimental group. The experimental group gives solution-focused counseling treatment, while the control group did not get this treatment. The control group used to compare the experimental group's results to compare the pretest and post-test between the control group and the experimental group. In the next stage, before the solution-focused counseling, the researcher conducted a pretest to the control group and the experimental group. When the counseling focused on the experimental group's solution, the next stage of this research is to post-test the experimental and control groups. The final step in this research is to analyze the pretest and post-test to determine whether the counseling focuses on practical solutions or is not used to make career decisions. The analysis results can also use to answer whether the research hypothesis is accepted or rejected.

\subsection{Population and Sample}

Population in experimental research is an absolute must, with the research population determining the examination [33]. This study's population was students majoring in Social Sciences at Muhammadiyah Senior High School, amounting to 47 people. The following is a detailed breakdown of the study population.

Table 1. Research population

\begin{tabular}{|c|c|c|c|c|}
\hline \multirow{2}{*}{ No } & \multirow{2}{*}{ Class } & \multicolumn{2}{|c|}{ Students } & \multirow{2}{*}{ Total } \\
\cline { 3 - 4 } & & Male & Female & \\
\hline 1 & $\begin{array}{c}\text { XI social } \\
\text { Sciences } 1\end{array}$ & 11 & 11 & 22 \\
\hline 2 & $\begin{array}{c}\text { XI social } \\
\text { Sciences 2 }\end{array}$ & 13 & 12 & 25 \\
\hline \multicolumn{2}{|c|}{ Total } & 24 & 23 & 47 \\
\hline
\end{tabular}

From this population, then identified so that research samples can found. The sample selection used purposive sampling. From the results of the purposive sampling analysis, it found that the study sample was 16 people. The sample consisted of eight women and eight men who had career choice problems. The sample selection obtains from the Likert scale analysis results, and 16 people had low career selection abilities. The class teacher also recommended the 16 people in question because they tended to experience confusion in determining career choices.

\subsection{Data Collection Techniques}

Appropriate data collection techniques also need to be taken into account so that when the data collection process is doing, it can produce objective and accountable data. Researchers who are involved directly in the field will allow for a more in-depth collection of research data. Researchers in this study used observation and a Checklist of Problems as a preliminary research data collection technique, while for data collection related to career choice using a scale.

From this observation process, it will be possible to determine what people need or what problems occur in the population. In this case, the researcher made observations to observe students' behavior in class XI social Sciences. The use of problem checklists shows things that have happened or are happening in a person's life, especially career selection. This process takes place by selecting and filling out the Problem Checklist according to the conditions they are experiencing. This study uses the Problem Checklist as a tool to find out how students' career choice decisions make.

\subsection{Research Instrument}

Researchers will use the Likert scale as an instrument in data collection. This research instrument is important because it is a tool to measure the understanding of research activities [34]. The scale uses to measure personality about career choices. The choice of answers on the Likert scale uses the options Strongly Disagree, Disagree, Agree, Strongly Agree, for all items listed on that scale according to the respondent's situation. The Likert scale used in this study consists of 61 items that measure the ability to make career decisions. The scale consists of three sub-studies, namely (1) knowledge and self-understanding of career choice decisions as many as 33 items, (2) knowledge of understanding the world of work in making career choice decisions 28 items, and (3) reasoning about the world of work with five items. The analysis used in this research is quantitative data analysis using the Paired-Sample T-Test, Paired-Sample T-Test, or better known as the Pre-Post Design. This design involves two measurements on the same subject to get a specific effect or treatment.

\section{Result}

The research analysis results showed that the researcher conducted a brief therapy group counseling focused on improving students' career choice decision-making at Senior High School Muhammadiyah 1 Palangkaraya. Researchers used a career choice understanding scale as a research data collection tool to determine the difference 
between the pretest and post-test results. Following are the results of the analysis in question

Table 2. The results of the pretest and post-test data analysis

\begin{tabular}{|c|c|c|c|c|c|c|}
\hline \multirow{2}{*}{ NO } & \multirow{2}{*}{ Name } & \multicolumn{2}{|c|}{ Experiment group } & \multirow{2}{*}{ Name } & \multicolumn{2}{|c|}{ Control Group } \\
\cline { 7 - 7 } \cline { 6 - 7 } & & Pretest & Posttest & & Pretest & Posttest \\
\hline 1 & AF & 152 & 201 & MM & 183 & 183 \\
\hline 2 & RAP & 177 & 182 & IL & 212 & 188 \\
\hline 3 & EMP & 174 & 181 & AM & 187 & 175 \\
\hline 4 & FN & 166 & 194 & MG & 178 & 182 \\
\hline 5 & AA & 177 & 176 & T & 180 & 189 \\
\hline 6 & NZ & 208 & 176 & M & 201 & 181 \\
\hline 7 & AAZ & 174 & 216 & MI & 176 & 188 \\
\hline 8 & AU & 194 & 193 & ZA & 169 & 169 \\
\hline
\end{tabular}

The pretest-posttest table analysis results for the experimental group and the control group above show that the eight control group and eight experimental group people have significant changes. Changes in scores between the experimental and control groups show that the difference a better seen in the experimental group than in the control group. The following is an explanation of the results of the calculation of SPSS in implementing solution-focused short therapy group counseling to improve career choice decision making at Muhammadiyah 1 Palangkaraya Senior High School. To clarify the following discussion following is presented in diagrammatic form.

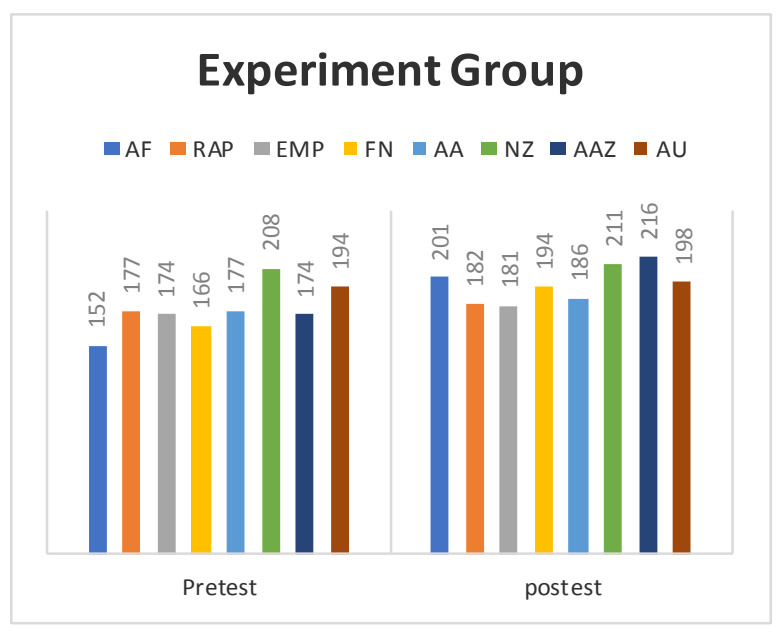

Figure 1. Experiment group

The experimental group analysis results showed that each student experienced a better chance, and it could prove by a post-test score that was better than the pretest score. The diagram analysis above can also understand that brief solution-focused counseling is useful for improving student career choice. AF students had an increase of 48 points, RAP students had an increase of 7 points, EMP had an increase of 7 points, the FN had a rise of 28 points, AA had an increase of 7 points, NZ had an increase of 3 points, AAZ had an increase of as much as 42 points, and the AU has increased by 4 points.

\section{Control Group}

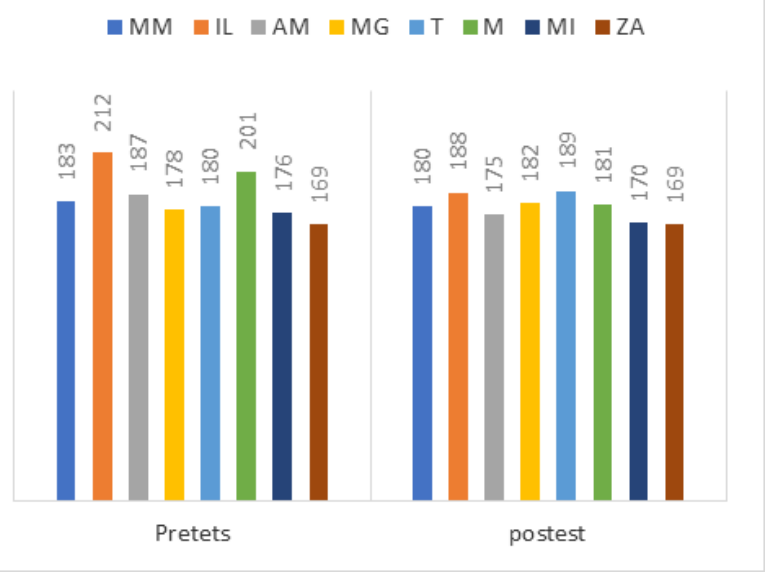

Figure 2. Control Group

The diagram above analysis clarifies that there is no significant change; the study results show that only one person has changed, namely the initials $\mathrm{T}$. Better among his classmates. Results of the Pretest and Posttest of the Experiment Group and the Control Group. The following is a presentation of the results of the SPSS calculations in the implementation of solution-focused brief Counseling group counseling to improve career choice decision-making student at Muhammadiyan 1 High School, Palangkaraya

Table 3. Paired Samples Statistics

\begin{tabular}{|c|c|c|c|c|c|}
\hline \multicolumn{2}{|c|}{} & Mean & N & Std. Deviation & $\begin{array}{c}\text { Std. Error } \\
\text { Mean }\end{array}$ \\
\hline \multirow{2}{*}{ Pair 1 } & Pretest & 62.00 & 8 & 6.164 & 2.055 \\
\cline { 2 - 6 } & Posttest & 110.33 & 8 & 5.635 & 1.878 \\
\hline
\end{tabular}

Based on the table above, it seems there was a process of increasing, on average, from 62.00 to 110.33. An average increase of 48.33 occurred. With the analysis results above, so that solution-focused counseling can increase the ability to make career decisions. The results of the analysis to test the hypothesis on the experimental group shows that Asymp. Sig (2-tailed) of 0.024, so it can conclude that the Asymp Sig. (2-tailed) <significant level $(\alpha / 2=0.05)$, which is 0.235 , which means that there is a significant effect.

Solution-focused counseling has a significant role in increasing understanding of career choice for students. The right career choice in life will help a person be more productive and develop better abilities according to his career choice. A career is an absolute thing in a person that ultimately must be chosen and lived. Studies conducted in Greece show that career choices are influence by gender stereotypes [35]. Men are more dominant in a career, as evidenced by men's presence in 
every career field choice. However, that does not mean that women have low career opportunities. Everyone has the same career opportunities and choices according to the abilities they have. So that students need to get support in choosing an appropriate career [36]. One of the services that can help students make the right career choice is counseling that focuses on solutions. This counseling service has proven to help students make career choices, as evidenced by the increase in the average from 62 to 110.33. This counseling service will guide students to be able to choose careers according to their talents and interests. The selection of the appropriate career will create a harmonious career path in his life. Students will not experience difficult career problems later if they receive careers and treatment from an early age. Solution-focused counseling services create a deep understanding of how to make a person responsible for his choices. Students also are guided in determining the right choice and according to their abilities.

\section{Conclusions}

The researchers concluded that from all the analysis results, it could see that the solution-focused brief therapy group counseling can improve career choice decision-making skills. The significant value of the t-test value $-1,700$, with a significance level of 0.234 . Because $t$ count $<$ table $(\mathrm{df}=7)$ with an amount of $-1,300>1,894$, the null hypothesis test is accepted, and the alternative hypothesis test is a reject. Whereas in the control group that was only given counseling treatment without special treatment, the t-test technique's significance value was 0.823 , with a significance level of 0.438 . Because $t$ count $<\mathrm{T}$ table $(\mathrm{df}=7)$ with a value of $0.823<1.894$, the null hypothesis test is accepted and alternative hypothesis testing. The hypothesis concluded a more significant effect of solution-focused therapy group counseling than group counseling without using techniques for retrieval career choice decisions. Suggestions in this study are other than parents who contribute in determining children's career choices. The school also plays an essential role in career choices. School is a bridge for children to be able to choose suitable career options. The school hopes to provide service facilities to students in providing career choice services. Guidance and counseling teachers in schools hope to be active in providing appropriate services so that children can develop their careers optimally. The right career choice will create job satisfaction and work motivation, and impact work productivity, getting better.

\section{Acknowledgments}

We want to express our deep gratitude to Muhammaidyah University Palangkaraya, who always supports both morally and materially to all lecturers at the Muhammadiyah Palangkaraya University for consistently working and producing quality publications.

\section{REFERENCES}

[1] Tohirin. Bimbingan dan Koseling (Berbasis Integrasi). Revisi. Jakarta: Rajawali Pers; 2013. 109-110 p.

[2] Bimo Walgito. Bimbingan konseling studi \&karier. Yogyakarta: Andi Offset; 2010.

[3] Whiston SC, Li Y, Goodrich Mitts N, Wright L. Effectiveness of career choice interventions: A meta-analytic replication and extension. J Vocat Behav [Internet]. 2017;100:175-84. Available from: http://dx.doi.org/10.1016/j.jvb.2017.03.010

[4] Maree JG. Connecting conscious knowledge with subconscious advice through career construction counselling to resolve career choice indecision. South African J Educ. 2020;40(April):1-13.

[5] Muspawi M. Menata Pengembangan Karier Sumber Daya Manusia Organisasi. J Ilm Univ Btanghari Jambi. 2017;17(1).

[6] Alabood A, Manakkattil S. The relationship between career maximization and employee engagement. Manag Sci Lett. 2020;10(11):2597-602.

[7] Cheng Y, Xue Y, Chang M. Career choice as an extended spatial evolutionary public goods game. Chaos, Solitons and Fractals. 2020;137:1-17.

[8] James L. Gibson et al. Organisasi : perilaku, struktur, dan proses. 2nd ed. Surabaya: Binarupa Aksara; 2014.

[9] Kassam AF, Cortez AR, Winer LK, Kuethe JW, Athota KP, Quillin RC. The impact of medical student interest in surgery on clerkship performance and career choice. Am J Surg [Internet]. 2020;219(2):359-65. Available from: https://doi.org/10.1016/j.amjsurg.2019.09.040

[10] Almutary H, Al-Moteri M. Psychometric properties of factors influencing Healthcare Career Choice Scale. Nurs Open. 2020;(May):1588-96.

[11] Hartinah Siti. Pengembangan Peserta Didik. Bandung: PT Refika Aditama; 2010.

[12] Mahadeo J, Hazari Z, Potvin G. Developing a computing identity framework: Understanding computer science and information technology career choice. ACM Trans Comput Educ. 2020;20(1):7-714.

[13] Tillmann T, Weiß S, Scharfenberg J, Kiel E, Keller-Schneider M, Hellsten M. The Relationship Between Student Teachers' Career Choice Motives and Stress-Inducing Thoughts: A Tentative Cross-Cultural Model. SAGE Open. 2020;10(2).

[14] Crossley ML, Mubarik A. A comparative investigation of dental and medical student's motivation towards career choice. Br Dent J. 2002;193(8):471-3.

[15] Ward AM, Kamien M, Lopez DG. Medical career choice 
and practice location: Early factors predicting course completion, career choice and practice location. Med Educ. 2004;38(3):239-48.

[16] Muhafidin D. Improving quality of higher education using academic information system as a public administration service: The case of Indonesia. J Soc Stud Educ Res. 2020;11(1):127-36.

[17] Dyrbye LN, Burke SE, Hardeman RR, Herrin J, Wittlin NM, Yeazel $M$, et al. Association of clinical specialty with symptoms of burnout and career choice regret among US resident physicians. JAMA - J Am Med Assoc. 2018;320(11):1114-30.

[18] Foon LW, Zainudin ZN, Yusop YM, Wan Othman WN. E-counselling: The intention, motivation and deterrent among school counsellors. Universal Journal of Educational Research, 2020;8(3):44-51. https://10.13189/ujer.2020.081605

[19] Saputra WNE, Supriyanto A, Astuti B, Ayriza Y, Adiputra S, da Costa A, et al. Peace counseling approach (PCA) to reduce negative aggressive behavior of students. Universal Journal of Educational Research, 2020;8(2):631-7. https://10.13189/ujer.2020.080236

[20] Arslan Ü, Çağatay İ. Çözüm Odaklı Kısa Süreli Terapi Eğitimi. 2020;9(January):1-12.

[21] Mumpuniarti M, Handoyo RR, Pinrupitanza DT, Barotuttaqiyah D. Teacher's pedagogy competence and challenges in implementing inclusive learning in slow learner. Cakrawala Pendidik. 2020;39(1):217-29.

[22] Sartinah EP, Purwoko B. The development of a theory book and practice manual for solution focused brief therapy (SFBT) counseling. Int $\mathrm{J}$ Innov Creat Chang. 2020;13(2):421-34.

[23] Yasfard G, Abaspour Azar Z, Hosseini Almadani SA. Comparing the Effectiveness of group Dialectical Behavior Therapy and Solution-Focused Brief Therapy on Self-Esteem, Cognitive-Emotional Regulation and Non-Suicidal Self-Injury in daughters. ranian J Heal Educ Heal Promot. 2019;7(4):343-58.

[24] Chen S. An online solution focused brief therapy for adolescent anxiety during the novel coronavirus disease (COVID-19) pandemic: A structured summary of a study protocol for a randomised controlled trial. Trials. 2020;21(1):21-3.
[25] Zatloukal L, Žákovský D, Tkadlčíková L. 'Kids' Skills’ and 'Mission Possible' Innovations: Solution-Focused Brief Therapy Models for Working with Children and Adolescents Revised and Expanded. Aust New Zeal J Fam Ther. 2020;41(1):29-41.

[26] Sumarwiyah et all. Solution Focused Brief Counseling (SFBC): Alternatif pendekatan dalam konseling keluarga. GUSJIGANG. 2015;1(2).

[27] Cannistrà F, Hoyt M. The Nine Logics Beneath Brief Therapy Interventions: A Framework to Help Therapists Achieve Their Purpose. J Syst Ther. 2020;39(1):19-34.

[28] Jordan SS, Froerer AS, Bavelas JB. Microanalysis of Positive and Negative Content in Solution-Focused Brief Therapy and Cognitive Behavioral Therapy Expert Sessions. J Syst Ther. 2013;32(3):46-59.

[29] Efford. Teknik Keterampilan Konselor. indonesia. Jakarta: Pustaka Pelajar; 2017.

[30] Turns B, Jordan SS, Callahan K, Whiting J, Springer NP. Assessing the Effectiveness of Solution-Focused Brief Therapy for Couples Raising a Child with Autism: A Pilot Clinical Outcome Study. J Couple Relatsh Ther [Internet]. 2019; 18(3):257-79. Available from: https://doi.org/10.108 0/15332691.2019.1571975

[31] Sugiyono \& Mitha Erlisya Puspandhan. metode penelitian kuantitatif, kualitatif, dan R\&D. Kamasturyani A, editor. Bandung: Alfabeta. Bandung: Alfabeta, CV; 2020.

[32] Creswell JW. research design: qualitative, quantitative and mixed method approach. USA: SAGE Publication; 2014.

[33] Creswell JW. Reseacrch Design Pendekatan Kualitatif, Kuantitatif dan Mixed. Achmad Fawai, editor. Yogyakarta: Pustaka Pelajar; 2010.

[34] Yusuf AM. Metode Penelitian Kuantitatif, Kualitatif \& Penelitian Gabungan. Jakarta: Prenada; 2014.

[35] Teliousi V, Zafiri M, Pliogou V. Occupation and gender stereotypes in primary school: The case of the english language coursebooks in Greek primary schools. Universal Journal of Educational Research, 2020;8(4):1135-48. https://10.13189/ujer.2020.080403

[36] Eriksson H, Högdin S, Isaksson A. Education and career choices: How the school can support young people to develop knowledge and decision-making skills. Universal Journal of Educational Research, 2018;6(9):1900-8. https://10.13189/ujer.2018.060907 